\title{
Translanguaging as an Effective Tool for Promoting the Use and Contribution of African Languages to Formal Education: the Nigerian Case
}

\author{
Michael AKINPELU \\ University of Regina \\ Saskatchewan, Canada
}

\begin{abstract}
:
As in many sub-Saharan African countries, language policy in Nigeria is essentially a continuation of the legacy that was bequeathed to it from colonization, highly favouring the use of English in official domains, including in education. In practice, English remains the main language of instruction in Nigeria at all levels of formal education and is considered the 'language of success' because of the socio-economic opportunities it procures. This policy has however proved ineffective because it continues to marginalize a great number of the Nigerian population rather than equipping it to contribute to development. Since good and effective education remains the best means by which people are empowered to participate in their personal and national development and that this is better achieved through an efficient use of mother tongues, we argue in this paper for the adoption of translanguaging approach in formal education in Nigeria and offer country-specific implementation strategies.
\end{abstract}

Keywords: Translanguaging, education, language policy, mother tongue, development

\section{Introduction}

Formal educational systems in Sub-Saharan Africa continue to be dominated by the exclusive use of inherited languages from colonization (French, English, Portuguese, Spanish), oftentimes to the detriment of endogenous languages which, due to their lack of official recognition, are usually relegated to informal uses. In nations where efforts seem to have been made to promote some of these languages, only major (numerically important) ones are habitually given some attention but are never fully elevated to the same status languages inherited from colonization enjoy. Yet, these languages constitute the main means of communication for African populations. As studies have revealed, only about $20-40$ percent of the continent's population could actually speak and write these inherited languages (Obanya, 1979; Simire, 2003; Adegbija, 2004; Chumbow, 2009). This situation constitutes a serious handicap to learning and transmission of knowledge in Africa and raises serious concerns about the overall development of the continent. Nigeria, a nation in West Africa, is no different. Building on the fact that quality education is a vital incentive to national development and language is an effective tool for achieving that, as it is "at the beginning, in the process and at the end of development, and the individual and his/her language is at the heart" (Djité 2008, p.48), this work considers the translanguaging approach as an effective pedagogical technique to promote the use and valuable contributions of African languages to formal education, which will in turn stimulate a greater and an active participation of the Nigerian population in the process of national development.

\section{Language Policies in Sub-Saharan Africa}

At the national level, the vast majority of African States practice a language policy of endorsement which is essentially a continuation of the language policy inherited from colonizers, since the colonial languages still holdall official functions (education, administration, justice, etc.). However, few of these countries (e.g. Nigeria) have also adopted a language policy of adaptation, a sectoral language policy that provides for the use of indigenous languages in some areas, especially in education, with the purpose of facilitating understanding and mitigating transition from home to school. This policy is generally formed on the belief that, because local languages are already well mastered by learners, they are best suited for communication and dissemination of knowledge in classrooms and literacy centres (Halaoui, 2011; Akinpelu, 2018).

It should be stressed nonetheless that in countries where this policy is practiced, the colonial language is not totally abandoned in favour of an indigenous language. Rather, local languages are only used in early years of education for effective transmission of knowledge and to promote optimal understanding of educational contents, because the colonial language is quickly introduced as the medium of instruction for the reminder of formal education. Notwithstanding, 
These language policies have direct implications on the literacy rate and the overall quality of education on the continent. According to Ouane and Glanz (2010), only 176 local languages are used in educational systems in Africa. This only represents about 8 percent of the 2,144 languages available on the continent, and none of these languages truly enjoys the same status as the languages inherited from colonization. In some cases, these languages appear in the national curriculum but are poorly implemented due to lack of teaching personnel or teaching materials (Akinnaso, 1991; Adegbija, 2004). In addition, studies have revealed that students drop out of school due to difficulties understanding the language of instruction (Macdonald, 1990; Alidouand Brock-Utne, 2006). Today, Africa remains the only continent where the majority of children have access to formal education in a foreign language.

\section{Language Policy in Nigeria}

Nigeria is one of the countries where the above described language policy is practiced. Although the country is essentially practicing a language policy of endorsement, provisions have been also made for mother tongue education albeit sporadically. The official curriculum document, the National Policy on Education (NPE), states that the language of instruction for the first three years of formal education is the child's mother tongue, if codified, otherwise a language of the immediate environment (usually Igbo, Yoruba or Hausa) is to be used. During these years, English language is learned as a subject. At the fourth year, however, the English language becomes the language of instruction for the remainder of the academic career, while the indigenous language is only taught as a subject. Definitely, this total reliance on these inherited languages, continues to nourish the idea that local African languages are inferior, intrinsically unable to convey science and new technologies (Adegbija, 2004; Ouédraogo, 2001). Coupled with this is the attitude of neglect towards the language issues often displayed by the leaders who either do not consider the language question urgent or simply choose to remain indifferent in the face of the enormity of the problem. This is well stated in the following remarks by Bamgbose (1991, p. 5-6):

The attitudes of African governments to language problems constitute another factor in the language question. Confronted with the colonial legacy and the difficulty of making a change, they oftentimes simply accept the situation as a fait accompli or they may remain indifferent. Sometimes, they are aware that there is a problem, but they are so overwhelmed by the magnitude of the problem that they stick to what already exists. It is only in a minority of cases that there have been brave attempts to face the problems squarely and take decisive policy measures; but even in such cases, the legacy of the past often limits what can be done. There is a general feeling that language problems are not urgent and hence solutions to them can wait.

Yet, there are many advantages associated with the use of local African idioms in formal education. Firstly, they are languages of the everyday life; education in foreign languages does not have direct impact on the social life. As Devonish (1986) rightly puts it: "The language variety spoken as the language of everyday communication by the ordinary members of a community is the most effective language medium for releasing creativity, initiative and productivity [...].Such a language is also the most effective means of promoting popular participation [...].” (p. 35)

Secondly, language policies in Africa as a whole have proved to be ineffective after 5 decades. They have resulted in the marginalization of a large portion of the population (often considered illiterates because they are unable to speak and write the languages) in the process of development. As noted by Bamgbose (2000), "[i]lliteracy is perhaps the most devastating source of exclusion, for not only are illiterates unable to participate using a country's official language, they cannot do so either using any other language in a written medium." (p. 3). Consequently, the sole dependency on colonial languages for development has proved to be rather illusory. Thirdly, studies have shown several advantages related with education in African languages (mother tongues). According to a report by the World Bank (2005), the use of first language instruction (language that children understand better) in Mali yielded many benefits, such as increased access and equity, improved learning outcomes and reduced repetition and drop-out rates. The report revealed for example that between 1994 and 2000, the pass rates for the end of primary level examination for children under convergent pedagogy (gradual transition from a local language to French) performed better than children in Frenchonly programs. It also showed that children that participated in the convergent pedagogy are 5 times less likely to retake their classes and 3 times less likely to drop out of school. Another study conducted in Botswana by BrockUtne\&Alidou (2006) indicated a better mastery of scientific concepts in Setswana than in English.

A study by Heugh et al. carried out in Ethiopia in 2007 revealed a better performance of $7^{\text {th }} \& 8^{\text {th }}$ grade students in mathematics and science between 2000 and 2004, because of the use of the mother tongue. The use of mother language education is also beneficial to teachers who speak the same langue with the children as this lets the teachers "to use more active and more effective teaching methods" (World Bank, 2005, p. 4). 
Given the many benefits associated with the use of the mother tongue in education, we advocate in this work for a revision of current language-in-education policies in Africa that only favour the use of imported languages and propose policies that take into account the useful and effective contribution of African languages in building human capital. To achieve this, we recommend the adoption of translanguaging techniques in educational systems in Africa, particularly in Nigeria.

\section{TRANSLANGUAGING: Origin and Definition}

The term "translanguaging" was coined and conceived as a pedagogical theory by Cen Williams (see Baker, 2006) to describe a bilingual teaching technique where reading and listening (input, reception) are done in one language and speaking and writing (output, production) in another language. It has been translated from the Welsh trawsieithuas "translanguaging" by Baker $(2006 ; 2011)$. The concept was later extended by García (2009) to all contexts of a multilingual life (home, street, school, work).

According to Baker (2011, p. 288), translanguaging is "the process of making meaning, shaping experiences, gaining understanding and knowledge through the use of two languages." For Canagarajah (2011, p. 401), it is "the ability of multilingual speakers to shuttle between languages, treating the diverse languages that form their repertoire as an integrated system." Wei (2011), on his part, considers translanguaging as "both going between different linguistic structures and systems, including different modalities (speaking, writing, signing, listening, reading, remembering) and going beyond them. It includes the full range of linguistic performances of multilingual language users..." (p. 1223). Garcia \& Wei (2014) have defined translanguaging as "the act of languaging between systems that have been described as separate, and beyond them" (p. 42). At the very core of this pedagogic method is the need to facilitating the learning process, using the learner's complete language repertoire - making sure the learner has understood and is being understood.

\subsection{Advantages of Translanguaging Pedagogy}

Studies have revealed several advantages of translanguaging. Contrary to the traditional view that perceives languages as separate entities, translanguaging is more encompassing and transformative in its approach, particularly as related to monolingual, bilingual, foreign and second language education (Garcia \&Wei, 2014).It is a learner-centred approach and based on bi/multilingual students' meaningful performance, although includes code-switching and translation (García, 2009, 2011). As such, it promotes deeper and fuller understanding of the subject matter and may help development of weaker language through cross-linguistic transfer (Baker, 2006; 2011; Cummins, 2008). In addition, translanguaging embraces creativity and criticality (Wei, 2011) and includes strategies meant to help improve students' speaking, listening, reading, and writing abilities. On the aspect of listening and speaking, translanguaging helps the learner to use detail heard in one language to give the sense/idea of it in another. In the area of reading and comprehension, it allows for a text to be read in one language and responses provided to questions in another language. In writing, it allows learners to summarize information received in one language in another.In sum, in its essence, translanguaging enhances or enriches the use of languages (multilingualism) in a dynamic manner for effective communication and language production - through the use of one language to reinforce the other to increase understanding (Lewis et al.,2012). This, in turn, can contribute to boost the learner's confidence and motivation (Creese \& Blackledge 2010).

\section{Translanguaging Pedagogy in Africa and in Nigeria}

Although the concept of translanguaging as a teaching approach continues to draw more and more attention among scholars and educators around the world, on the African continent, only very few experimentations of translanguaging practices have been conducted, mainly in South Africa. Madiba's study in 2014 revealed that a simultaneous use of Tshivenda, isiXhosa and English in science classes at the University of Cape Town greatly aided the understanding of the subject matter. Another study by Makalela (2015) indicated how the use of Sepedi, isiZulu, isiNdebele, SiSwati and English in teacher preparation and training program promoted deep understanding of the content and efficacy of the overall activity. A recent study by Hurst and Mona (2017) advocates for a translanguaging pedagogy as a means of decolonizing the university curriculum in South Africa, following positive responses from students who generally appreciated the opportunity to use their own languages in education.

In Nigeria, the focus of our study, no known study has been found using the translanguaging techniques in formal education in Nigeria. However, the current situation in the country begs for a more effective and well-oriented pedagogical approach that makes a good use of local languages in education. The country's overall educational system is facing several challenges including the academic performance of the students. The drop-out rate, according to Fafunwa et al. (1989, as cited in Fasokun, 2008), is estimated to be between 40-60 percent. This is corroborated by data 
from UNESCO (2020) that state that in 2009 only 64 percent of elementary pupils actually survived to the last grade while only 60 percent transitioned from primary to secondary. In addition, according to Umoru (2018), the nation has been recording 70 percent failure in secondary level examinations since 2009. Many causes are responsible for these challenges, including an inadequate and defective language-in-education policy (Bamgbose, 1991). The premature introduction of English as the language of instruction could largely account for this. Students tend to struggle with new concepts and language forms due to the difficulty in using English as effective means of instruction and learning. There is also no continuity and early disconnect between language used at school and the language used for daily life (Okwori et al, 2014). According to the UNESCO EFA Global Monitoring Report (2013/2014), the current state of education in Nigeria makes the country to lose a lot of money because children are actually not learning, due to poor quality of education.

This state of things, together with the low interest in mathematics and science subjects growing among Nigerian pupils have prompted Ogbonaya Onu, the Minister of Science and Technology, during a visit to Ekulu Primary School in Enugu to seriously consider the use of indigenous languages (mother tongue) in primary education, attributing the low interest to the lack of understanding of subject matter in foreign language:

The Ministry of Science and Technology is worried over the low interest in mathematics and the science subjects. So, we are working on plans to teach mathematics and sciences in indigenous languages in primary schools. These pupils grow up with their indigenous languages at home before they start going to school, where they are now taught in foreign languages. So, we have observed that there is a challenge to understand the foreign languages first before they could even start understanding what they are being taught. We believe that this plan will help our students to understand mathematics and the science subjects, and also promote the application of science and technology for national development (OgbonayaOnu, Minister of Science and Technology, as cited in Lawal, 2017, para 10 \& 11).

Considering that the Nigerian children undergo unnecessary emotional and intellectual hurt by teaching them in foreign language at the elementary age, the minister further stressed the importance of an education in mother tongue as a means to better equip them during the first twelve years of their lives.

It is our contention that a child, if helped to lay the foundation of his future development in his own mother tongue, will likely be in a position to build upon it in later years even in another language. We are, therefore, constrained to ask whether this serious defect in our colonial pattern of education has not robbed the child of inventiveness, originality and creativity since he is forced to think in English instead of Yoruba, Hausa, Igbo or any other Nigerian language. (OgbonayaOnu, Minister of Science and Technology, as cited in Adesulu, 2017, para. 18)

This declaration by the Nigerian Minister of Science and Technology echoes the position of the former education minister, Aliu Babatunde Fafunwa, who actually championed mother tongue education in the country with hisIfe SixYear Primary Project (SYPP) conducted between 1970 and 1989 at the University of Ife (now Obafemi Awolowo University) using a local language (Yoruba) as the medium of instruction for subjects including science mathematics during the entire primary education. The outcomes of Fafunwa's project proved convincingly that learning is best achieved in the child's mother tongue. Not only did the use of a mother tongue as language of instruction help reduce the drop-out rate among the experimental group, students who participated in the study also performed better in secondary school than their counterparts in the regular program (Fasokun, 2008).

Fafunwa's pioneering works offer a good basis for the adoption of translanguaging as a pedagogic approach in Nigeria. More precisely, in the Nigerian education system, translanguaging techniques would be most beneficial if adopted for basic education (9-year duration comprising of 6 years of primary education and 3 years of junior secondary education). Many reasons help support this claim. Firstly, as regarding primary education: according to the national curriculum, the Nigerian government considers primary education as the foundation of its education system and the remainder of the system depends on it and therefore it is viewed as "the key to the success or failure of the whole system" (National Policy on Education, 2004, Section 4, Article 17). This explains why this level of education is designed with specific goals in mind, including providing the child with permanent literacy and numeracy; a sound foundation for scientific and reflective thinking; and basic tools for educational advancement, among many others (National Policy on Education, 2004, Section 4, Article 18).

Using translanguaging techniques as a learning method at this level would contribute in a meaningful way to achieving the goals set for this level. As it is now, the national curriculum provides for the use of a Nigerian language as language of instruction during the first 3 years while English is taught as a subject. At the fourth year, roles are switched, English 
takes on the role of language of instruction while the local language is taken as a subject. It goes without saying that this approach is not helping to achieve educational goals at this level and has raised serious concerns among scholars and stakeholders (see for example concern raised by the Minister of Science and Technology above).Rather than simply abandoning the local language in favour of the English language as the medium of instruction in the $4^{\text {th }}$ year, we suggest an intentional and official recognition of the useful contribution of the local language by making a provision for it to be used to reinforce English in education, particularly in mathematics and science subjects where students are already struggling to grasp concepts. And translanguaging is an effective method for accomplishing this, as it allows for the simultaneous use of L1 and L2 in classrooms for better learning, while promoting creativity (ingenuity, inventiveness) and criticality (ability to process and synthesize information), two notions considered fundamental to translanguaging universe (Wei, 2011). A good performance at this level would go a long way to instil in the child the confidence to further with his or her education, thereby reducing drop-out rate that is presently high at the national level, as noted earlier.

Secondly, being the first of two stages of secondary education, the junior secondary level education has been designed to be both academic and pre-vocational and seeks to empower the students "to acquire knowledge and skills." (National Policy on Education, 2004, Section 5, Article 24 (a)). Depending on their academic ability and vocational interest, upon completion of their junior secondary school, students are streamed into: (1) a senior secondary school; (2) a technical college; (3) an out-of-school vocational training centre; or (3) an apprenticeship scheme. This level of education represents a milestone in the Nigerian education system and therefore plays an important role in determining the types of human resources and human capital that will eventually be available to participate in nation building and in development as a whole. This is the level in which talents are discovered and nurtured for future roles and contributions in the society at large. Consequently, the kind of education offered at this level is crucial. The adoption of the use of translanguaging method in junior secondary school, especially in core subjects (such as mathematics, integrated science, social studies, introductory technology) and some prevocational electives (such as agriculture, computer education and business studies) would considerably help prepare competent individuals for whichever stream they choose to pursue after completing their program.

Indeed, many advantages can be drawn from the adoption at the two levels of education that also form basic education presented above. Because basic education is free and compulsory, it provides the opportunity to offer better education to a greater number of students through the acquisition of relevant skills necessary for both personal and national development. Also, it will help promote dual literacy - produce individuals able to speak, read and write well in at least two languages (English and their mother tongue or major language in their environment). Furthermore, it will improve citizenry participation in the process of sustainable development of the nation. Moreover, the proposed educational approach put forward in this paper concurs with Nigeria's philosophy of education which revolves around the need for practical education, that is an education that is "geared towards self-realization, better human relationship, individual and national efficiency, effective citizenship, national consciousness, national unity, as well as towards social, cultural, economic, political, scientific and technological progress." (National Policy on Education, 2004, Section 1, Article 6). Attaining this requires an effective means of communication in education. And using local idioms (languages better understood by learners) to reinforce English language in education (translanguaging) is a great way to maximize understanding and offer better and relevant education to all.

\section{Conclusion}

The thesis expounded in this paper is that which calls into question the present state of formal education in Africa in general, and particularly in Nigeria, where total dependency on colonial languages inherited from colonization continues to hinder considerably the training of human capital and the contribution of the masses in the development process. As a multilingual nation, Nigeria stands to gain a lot from the adoption of translanguaging pedagogic techniques, if used for its basic education (9-year period) which, because it is free and compulsory, will provide solid foundation for future training and help build competent human capacity. The idea put forward here is not a call of total replacement of education in English language with local languages, but rather a useful contribution of local languages (already well known) to reinforce education in English language, backed by a policy from the government. From a linguistic point of view, this would also result in raising citizens who are both competent in their mother tongue and English.

In an age in which most developed countries seem to shift more and more towards knowledge economy - a move from traditional economy to knowledge-based economy - (Piotrowski, 2015), Africa cannot afford to continue to lag behind, due to the almost complete absence in the creation and production of knowledge. 
African nations are far from meeting the criteria for knowledge economy which, according to Chen and Dahlman (2006, p. 4) are built upon four pillars: (1) an economic incentive and institutional regime for good economy policies; (2) educated and skilled workers capable of creating and using knowledge efficiently; (3) an effective innovation system (research centres, universities, etc.); and (4) a modern and adequate information infrastructure for effective communication, processing and distribution of information and knowledge. It seems to us that a good education is at the heart of this, as it helps to produce highly skilled human resources that are not only able to create knowledge but also able to use it for domestic economy development. As noted by Bamgbose (1991): "A wider and more satisfactory conception of national development is that it is concerned with total human development. In this sense, education in general and mass participation in the economic process are vital to development; and the only way to ensure mass involvement is to pay attention to the use of indigenous languages in education [...]. Given Africa's high illiteracy rates, there does not seem to be any other viable alternative." (p. 7). This begs for good and well adapted language-ineducation policies that promote effective dissemination of information and communication. In Africa and most especially in Nigeria, the adoption of translanguaging techniques in education seems extremely promissory.

\section{References}

Adegbija, E. (2004). Language Policy and Planning in Nigeria. Current Issues in Language Planning 5(3), 181-246.

Adesulu, D. (2017, February 2).Teaching maths, sciences in mother tongues: The hurdles.

Vanguard,Nigeria.

https://www.vanguardngr.com/2017/02/teaching-maths-sciences-mother-tongues-hurdles/

Akinnaso, F. N. (1991). Toward the Development of a Multilingual Language Policy in Nigeria.Applied Linguistics, 12(1), 21-61.

Akinpelu, M. (2018). The Promotion of Languages in Nigeria: An Example of Problematic Official Multilingualism in Africa. In G. Lane-Mercier, D. Merkle and J. Koustas (Eds.), Minority languages, national languages, and official language policies (pp. 231-250). McGill-Queen's University Press.

Alidou, H.\& Brock-Utne. B. (2006a). Experience I - Teaching Practices -Teaching in a Familiar Language. InH.

Alidou, A. Boly, B. Brock-Utne,Y. S. Diallo, K. Heugh \& E. Wolff (Eds.), Optimizing learning andeducation in Africa - the language factor. A stock-taking research on mother tongueand bilingual education in sub-Saharan Africa (pp. 85-100). Association for theDevelopment of Education in Africa (ADEA), UNESCO Institute for Education (UIL),Deutsche Gesellschaft fürTechnischeZusammenarbeit (GTZ). Working Documentfor the ADEA Biennial 2006, Libreville, Gabon, March 27-31.

Alidou, H. \& Brock-Utne. B. (2006b). Experience II - Active Students - Learningthrough a language they master. InH. Alidou, A. Boly, B. Brock-Utne,Y. S. Diallo, K. Heugh \& E. Wolff (Eds.), Optimizing learning andeducation in Africa - the language factor. A stock-taking research on mother tongueand bilingual education in sub-Saharan Africa (pp. 101-117). Association for theDevelopment of Education in Africa, UNESCO Institute for Education, DeutscheGesellschaft fürTechnischeZusammenarbeit. Working Document for the ADEABiennial 2006, Libreville, Gabon, March 27-31.

Baker, C. (2011). Foundations of bilingual education and bilingualism ( $5^{\text {th }}$ ed.). Clevedon, UK:Multilingual Matters. Baker, C. (2006). Foundations of bilingual education and bilingualism ( $4^{\text {th }}$ ed.). Clevedon, UK:Multilingual Matters. Bamgbose, Ayo. (2000). Language and exclusion. The consequences of language policies in Africa. Hamburg: LIT Verlag Munster.

Bamgbose, Ayo. (1991). Language and the nation. The language question in sub-Saharan Africa. Edinburgh: Edinburgh University Press.

Canagarajah, S. (2011). Translanguaging in the classroom: Emerging issues for research and pedagogy. Applied linguistics review 2, 1-27).https://doi.org/10.1515/9783110239331.1.

Chen, D. H. C \&Dahlman, C. J. (2006). The Knowledge Economy, the KAM Methodology and World Bank Operations. The International Bank for Reconstruction and Development/The World Bank.

Chumbow, B. S. (2009). Linguistic Diversity, Pluralism and National Development in Africa. Africa Development34(2): 21-45.

Creese, A. \& Blackledge, A. (2010). Translanguaging in the Bilingual Classroom: APedagogy for Learning and Teaching. The Modern Language Journal, 94(1), p. 103-115.

Cummins, J. (2008). Teaching for transfer: Challenging the two solitudes assumptionsin Bilingual Education. InJ. Cummins (Ed.). Encyclopedia of Language andEducation, 5, 65-75.

Devonish, H. (1986).Language and liberation: Creole language politics in the Caribbean.London :Karia Press. Djité, P.G. (2008). The Sociolinguistics of Development in Africa. Clevedon/Buffalo/Toronto: Multilingual Matters.

Fafunwa, A.B., Macauley, J.I.\&Sokoya, J.A.F. (Eds.).(1989). Education in mother tongue: The Ife primary research project, 1970-1978.Ibadan, Nigeria, University Press. 
Fasokun, T. O. (2008). Fafunwa, Aliu Babatunde (1923-). Thinkers on Education. International Bureau of Education. http://www.ibe.unesco.org/en/document/thinkers-education.

Federal Republic of Nigeria. (2004). National Policy on Education, $4^{\text {th }}$ Edition.

García, O., \& Wei, L. (2014). Translanguaging: Language, bilingualism and education. PalgraveMacmillan.

Garcia, O. (2011). From language garden to sustainable languaging: Bilingual education in aglobal world. Perspectives 34(1), 5-9.

García, O. (2009). Bilingual education in the $21^{\text {st }}$ Century: A global perspective. Oxford: Wiley-Blackwell.

Halaoui, N. (2011). Politique linguistique: faits et théorie. Paris: Éditions Écriture.

Heugh, K., Benson C., Bogale, B.\&Yohannes, M. A. G. (2007). Final report study on medium of instruction in primary schools in Ethiopia, 22 January 2007. Ministry of Education, Ethiopia.

Hurst, E.\&Mona, M. (2017). "Translanguaging" as a socially just pedagogy. Education as Change, 21(2),126-148.

Lawal, I. (2017, June 15). Indigenous languages as tools for technological advancement. The Guardian Newspaper Nigeria, https://guardian.ng/features/indigenous-languages-as-tools-for-technological-advancement/.

Lewis, G., Jones, B., \& Baker, C. (2012). Translanguaging: origins and development from school to street and beyond. Educational Research and Evaluation, 18(7), 641-654.

Macdonald, C. A. (1990). Crossing the threshold into standard three in black education: Theconsolidated main report of the threshold project. Pretoria: Human Sciences Research Council.

Madiba, M. (2014). Promoting concept literacy through multilingual glossaries: A translanguaging approach. In C. Van der Walt \& L. Hibbert (Eds.). Multilingual Teaching and Learning in Higher Education in South Africa (pp. 68-87). Clevedon: Multilingual Matters.

Makalela, L. (2015). Moving out of linguistic boxes: the effects of translanguaging strategies formultilingual classrooms. Language and Education, 29(3), 200-217.https://doi.org/10.1080/09500782.2014.994524 Nigeria. UNESCO Institute for Statistics, Retrieved April 20, 2020, from http://uis.unesco.org/country/NG.

Obanya, P. A. I. (1979). Nigerian schools and the nation's problems. Journal of EducationalAdministration and History, 11(1), 50-55. https://doi.org/10.1080/0022062790110108.

Okwori, R. O., Ma'aji, A.S, Kareem, W.B.\&Attaochu, E. U.(2014). Drop out among Basic Technology Students in Nigerian Educational System: Causes, Effects and Remedies.Journal of Educational Policy and Entrepreneurial Research, 1(2), 204-210. http://jeper.org/index.php/JEPER/article/viewFile/34/34.

Ouane, A., Glanz, C.(2010). Why and how Africa should invest in African languagesand multilingual education. An evidence- and practice-based policy advocacy brief. UNESCO Institute for Lifelong Learning. Hamburg, Germany.

Ouédraogo, R. M. (2001). "Planification et politiques linguistiques danscertains pays sélectionnésd'Afrique de l'Ouest,"Institut International pour le Renforcement des Capacitésen Afrique, UNESCO, Addis Abéba.

Piotrowski, J. (2015). What is knowledge economy?Sci Dev Net, https://www.scidev.net/global/knowledge-economy/feature/knowledge-economy-ict-developing-nations.html.

Simire, G. O. (2003). Developing and Promoting Multilingualism in Public Life and Society in Nigeria. Language, Culture and Curriculum 6 (2), 231-43.

Umoru, H. 2018. "Senate summons Education Minister over mass failure in WAEC results." Nigerian Vanguard, https://www.vanguardngr.com/2018/03/senate-summons-education-minister-mass-failure-waec-results/.

UNESCO (2014).Teaching and Learning: Achieving Quality for All. The Education for All Global Monitoring Report 2013/04. https://unesdoc.unesco.org/ark:/48223/pf0000225654.

Wei, L. (2011). Moment Analysis and translanguaging space: Discursive construction of identitiesby multilingual Chinese youth in Britain. Journal of Pragmatics, 43, 1222-1235.

World Bank. (2005). In Their Own Language ... Education for All. Retrieved from http://documents.worldbank.org/curated/en/374241468763515925/pdf/389060Language00of1Instruct01PUBL

IC1.pdf 